\title{
Community Empowerment In The Selection of Contraception Equipment For Women of Worthy Age in Benteng Village
}

\author{
Yanti Srinayantia), Jajuk Kusumwaty, Rosmiati, Yudha Hendriana, Rizky Melaty \\ Sukma, and Sumilar Saena
}

\author{
STIKes Muhammadiyah Ciamis, Ciamis, Indonesia \\ a)Corresponding author: zeevanayanti80@gmail.com
}

\begin{abstract}
In general, family planning can be defined as an effort to regulate the number of pregnancies in such a way that it will have a positive impact on the mother, baby, father and family concerned and will not cause harm as a direct result of the pregnancy. Family planning is an attempt to regulate the population or the use of methods to regulate fertilization to help a person or family achieve certain goals. The purpose referred to here is an intentional arrangement of pregnancy by the family, which is not against the applicable laws or regulations and also the morals of Pancasila and for the welfare of the family. Giving understanding to couples of childbearing age that there are various kinds of contraceptives and their benefits, so that people can choose any contraceptive that suits the individual. With more benefits than side effects, especially to keep the pregnancy distance, and a prosperous family can be achieved. It is hoped that with careful family planning, pregnancy is something that is really expected so that it will avoid the act of terminating a pregnancy with abortion. Ciamis Regency is in the province of West Java, where the area is directly adjacent to two regencies, namely Banjar and Tasikmalaya. Its location in the center of the city makes the Benteng village not like a village in general.
\end{abstract}

Keywords : contraception, empowerment, equipment

\section{INTRODUCTION}

Pereng environment is one part of the Benteng Village, Ciamis Regency, West Java Province. Based on the survey results, there are about 18 couples of childbearing age who do not use contraception, $10 \%$ use birth control pills and about $12 \%$ use birth control injections. The community of couples of childbearing age The environment is mostly housewives and the education level is dominated by elementary school graduates or equivalent. Ciamis district itself is a pretty good area in the movement of Family Planning Control and Women's Empowerment, but still information about contraception is still not evenly distributed so that the Pereng environment is one of the ones where knowledge about the selection of contraceptives is still uneven.

The Family Planning Program (KB) is carried out in order to regulate the number of births or space births. The target of the family planning program is Couples of Childbearing Age (PUS), which is more focused on the group of women of childbearing age (WUS) who are in the age range of 15-49 years. This has led to the development of various contraceptive methods (Suratun et al., 2008).

Contraception is an effort made to prevent pregnancy that is temporary or permanent. Contraception can be done without using a device, mechanically, using a device/drug, or with surgery. There are various kinds of contraceptive options, one type of contraception is the IUD which is an effective method of contraception (Manuaba, 2010). The choice of contraceptive type is based on the purpose of use, namely delaying the couple's pregnancy, spacing pregnancies (regulating fertility) and ending fertility. Currently, there are many kinds of contraceptives circulating, including: pills, injections, IUDs and implants (Hartanto, 2010)

Contraceptive devices should meet the requirements, namely safe and reliable use, no adverse side effects, duration of action can be adjusted according to desire, and does not interfere with sexual relations (Setiawan, Khairunnisa, \& Oktavia, 2021). However, there are still many couples 
of childbearing age (EFA) who are still reluctant to use contraceptives, this is not only due to the limited methods available but also because of their ignorance about the requirements and safety of these contraceptive methods, various factors must be considered including health status (Suratun et al., 2008)

\section{METHOD}

The methods used in this activity include: seminars and discussions with women in the Pereng neighborhood of the Citadel sub-district, Ciamis district related to knowledge about family planning by observing the $3 \mathrm{M}$ health protocol, namely wearing masks, washing hands, keeping a distance. Through several stages as follows:

1. Preparation Stage

The preparatory stages include:

- Initial survey, at this stage a survey is carried out

- Location and target determination

After the survey, the location of the implementation and the target of the activity participants are determined.

- Prepare materials, training materials, among others: in the form of slides, papers for health education activities.

2. Stages of Implementation of Extension

Next will be given an explanation of the material on family planning, this session focuses on providing an explanation of how to run a family planning program, understanding contraceptives, explaining the types of contraceptives and others.

3. Extension Stage In the implementation of this activity, several training methods are used, namely:

- Lecture method

Through lectures to convey an explanation about family planning

- Question and Answer Method Through the question and answer method, it provides opportunities for extension participants to get as much explanation and knowledge as possible

\section{RESULT AND DISCUSSION}

The implementation of community service activities is aimed at Fertile Age Couples, this activity is carried out for 1 day, namely March 3, 2021. The counseling participants are 18 people. The place for this community service activity is located at SDN 03 Pereng. The implementers in this community service activity are lecturers and undergraduate students in Nursing.

Counseling about contraception was conducted through lectures and brought some examples of contraceptives. In addition to lectures, educational videos, power points and leaflets are also supported. The process of this activity is of course assisted by cadres in the Pereng Environment. Couples of childbearing age who are participants pay attention to health education regarding the selection of contraceptives. EFA also pays attention to the explanation of the terms of contraception itself (Firmansyah et al., 2021; Setiawan et al., 2021).

After the health education was conducted, couples of childbearing age understood what contraceptives were used to maintain pregnancy distance apart from the pills and injections that were previously known. As for the benefits of this counseling, it is hoped that couples of childbearing age are able to identify which contraceptive method is suitable for each (active) couple so that there are no more couples of childbearing age who do not use contraceptives to prevent pregnancies under 20 years of age and to prevent birth spacing.

\section{CONCLUSION}

Based on the activities that have been carried out, it can be concluded several things, namely:

1. Couples of childbearing age better understand the importance of using contraceptives

2. Couples of childbearing age know more about what contraceptives are simple, effective and safer

3. Couples of childbearing age can find out which contraception is more suitable for them 
4. Couples of childbearing age better understand the benefits and side effects of various contraceptive methods so that participants can choose and adjust which contraceptive method can be used safely for themselves and their partners

\section{REFERENCES}

Firmansyah, A., Setiawan, H., \& Ariyanto, H. (2021). Studi Kasus Implementasi Evidence-Based Nursing: Water Tepid Sponge Bath Untuk Menurunkan Demam Pasien Tifoid. Viva Medika: Jurnal Kesehatan, Kebidanan Dan Keperawatan, 14(02), 174-181.

Hartanto, H. (2010). Keluarga Berencana dan Kontrasepsi. Cetakan Ke-Lima.

Manuaba, I. (2010). Ilmu Kebidanan, Penyakit Kandungan dan Keluarga Berencana Untuk Pendidikan Bidan.

Setiawan, H., Ariyanto, H., Khaerunnisa, R. N., Firdaus, F. A., \& Fitriani, A. (2021). Yoga Improves Quality of Life among Breast Cancer Patients. Faletehan Health Journal, 8(01), 1-9. https://doi.org/10.33746/fhj.v8i01.159

Setiawan, H., Khairunnisa, R. N., \& Oktavia, W. (2021). Handwashing Health Education to Prevent Covid-19 Transmission in SMP Inspirasi. Abdimas UMTAS, 4(1), 428-432.

Suratun, H, Tien, \& Rusmiati. (2008). Pelayanan Keluarga Berencana dan Pelayanan Kontrasepsi.

Sudibia, I. K., Dewi, P. M., \& Yuliarmi, N. N. (2016). Keluarga berencana dan kesehatan reproduksi. Jurnal Udayana Mengabdi, 15(September), 252-259.

Tinggal, T., Dan, P., \& Bekerja, S. (2019). Wanita Sudah Menikah Dengan Pemakaian Kontrasepsi Hormonal Di Indonesia Tahun 2017 Relationships among Reproductive Ability, Child Ownership , Housing , Contraception in Indonesia in 2017. E-Jurnal Kebidanan, 22(2), 9198. http://dx.doi.org/10.22435/hsr.v

Yanty, R. D. (2019). Faktor Yang Mempengaruhi Pemilihan Jenis Kontrasepsi Pada Wanita Usia Subur. Jurnal Ilmiah Kesehatan Sandi Husada, 10(2), 121-124. https://doi.org/10.35816/jiskh.v10i2.127

Zuraidah. (2017). Pengaruh Pengetahuan Terhadap Persepsi Istri Dalam Penggunaan Kb Non Hormonal. Midwife Journal, 3(01), 1-8. www.jurnal.ibijabar.org 


\section{APPENDIX}

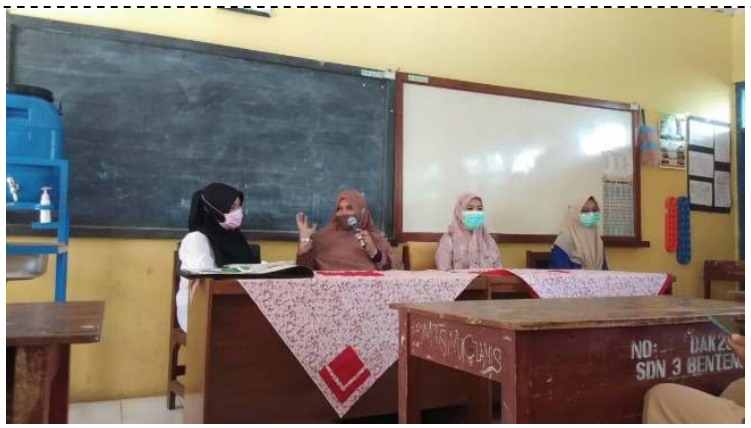

Figure 1. Wellcoming Speak

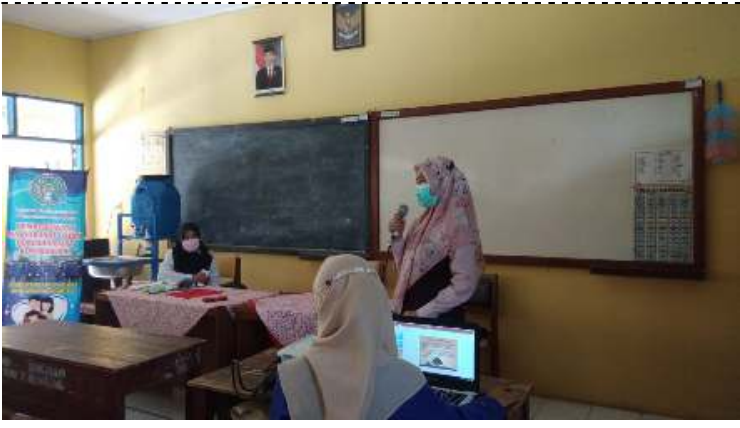

Figure 2. Health Education Session 